\title{
Effect of pre-diabetes on future risk of stroke: meta-analysis
}

\author{
(C) $(1) \Theta$ OPEN ACCESS
}

\author{
Meng Lee instructor ${ }^{1}$, Jeffrey L Saver professor ${ }^{2}$, Keun-Sik Hong professor ${ }^{3}$, Sarah Song instructor ${ }^{2}$, \\ Kuo-Hsuan Chang assistant professor ${ }^{4}$, Bruce Ovbiagele professor ${ }^{5}$
}

${ }^{1}$ Chang Gung University College of Medicine, Chang Gung Memorial Hospital, Chiayi, Taiwan; ${ }^{2}$ Stroke Center, Geffen School of Medicine, University of California, Los Angeles, CA, USA; ${ }^{3}$ Department of Neurology, Ilsan Paik Hospital, Inje University, South Korea; ${ }^{4}$ Chang Gung University College of Medicine, Chang Gung Memorial Hospital, Linkuo, Taiwan; ${ }^{5}$ Stroke Center and Department of Neuroscience, University of California, 9500 Gilman Drive, \#9127, La Jolla, San Diego, CA 92093-9127, USA

\begin{abstract}
Objectives To assess the association between pre-diabetes and risk of stroke, and to evaluate whether this relation varies by diagnostic criteria for pre-diabetes.
\end{abstract}

Design Systematic review and meta-analysis of prospective studies.

Data sources A search of Medline, Embase, and the Cochrane Library (1947 to 16 July 2011) was supplemented by manual searches of bibliographies of key retrieved articles and relevant reviews.

Selection criteria Prospective cohort studies that reported multivariate adjusted relative risks and corresponding $95 \%$ confidence intervals for stroke with respect to baseline pre-diabetes were included.

Data extraction Two independent reviewers extracted data on pre-diabetes status at baseline, risk estimates of stroke, study quality, and methods used to assess pre-diabetes and stroke. Relative risks were pooled using random effects models when appropriate. Associations were tested in subgroups representing different characteristics of participants and studies. Publication bias was evaluated with funnel plots.

Results The search yielded 15 prospective cohort studies including 760 925 participants. In 8 studies analysing pre-diabetes defined as fasting glucose $100-125 \mathrm{mg} / \mathrm{dL}$ (5.6-6.9 mmol/L), the random effects summary estimate did not show an increased risk of stroke after adjustment for established cardiovascular risk factors $(1.08,95 \%$ confidence interval 0.94 to $1.23 ; P=0.26)$. In 5 studies analysing pre-diabetes defined as fasting glucose $110-125 \mathrm{mg} / \mathrm{dL}(6.1-6.9 \mathrm{mmol} / \mathrm{L})$, the random effects summary estimate showed an increased risk of stroke after adjustment for established cardiovascular risk factors $(1.21,1.02$ to $1.44 ; \mathrm{P}=0.03)$. In 8 studies with information about impaired glucose tolerance or combined impaired glucose tolerance and impaired fasting glucose, the random effects summary estimate showed an increased risk of stroke after adjustment for established cardiovascular risk factors (1.26, 1.10 to $1.43 ; \mathrm{P}<0.001)$. When studies that might have enrolled patients with undiagnosed diabetes were excluded, only impaired glucose tolerance or a combination of impaired fasting glucose and impaired glucose tolerance independently raised the future risk of stroke $(1.20,1.07$ to 1.35; $P=0.002$ ).

Conclusion Pre-diabetes, defined as impaired glucose tolerance or a combination of impaired fasting glucose and impaired glucose tolerance, may be associated with a higher future risk of stroke, but the relative risks are modest and may reflect underlying confounding.

\section{Introduction}

The growing obesity epidemic in the United States has been inextricably linked with a surge in rates of pre-diabetes. ${ }^{1}$ Pre-diabetes has been called "America's largest healthcare epidemic,"1 and current estimates indicate that about $35 \%$ of adults in the United States have pre-diabetes, or approximately 79 million people. This number is more than three times the number of people with frank diabetes ( 26 million people). ${ }^{2}$ Also concerning is that the overwhelming majority of people with pre-diabetes may be unaware of their risk of diabetes. ${ }^{3}$

Pre-diabetes is generally defined as impaired fasting glucose, impaired glucose tolerance, or both. ${ }^{4}$ In 1997 the American Diabetes Association defined impaired fasting glucose as a plasma glucose concentration of 110 to $125 \mathrm{mg} / \mathrm{dL}$ (6.1-6.9 mmol/L). ${ }^{5}$ However, in 2003 the American Diabetes Association redefined impaired fasting glucose as a plasma concentration of 100 to $125 \mathrm{mg} / \mathrm{dL}(5.6-6.9 \mathrm{mmol} / \mathrm{L}){ }^{6}$ The underlying pathophysiological disturbances (insulin resistance and impaired $\beta$ cell function) responsible for the development of type 2 diabetes are expressed in people with pre-diabetes. ${ }^{7}$ People with pre-diabetes harbour the same vascular risk factors (dysglycaemia, hypertension, dyslipidaemia, obesity, physical inactivity, insulin resistance, endothelial dysfunction, 
pro-coagulant state, and inflammation) that place people with type 2 diabetes at high risk of macrovascular complications. ${ }^{7}$ Pre-diabetes has been linked to a modest increase in overall cardiovascular events, ${ }^{8}$ but the effect of pre-diabetes on risk of future stroke has not been established.

The objective of this study was twofold: to investigate the direction and magnitude of the relation of pre-diabetes with risk of future stroke after accounting for other stroke risk factors, and to evaluate whether this relation varies on the basis of the threshold for impaired fasting glucose or inclusion of impaired glucose tolerance criteria in the diagnosis of pre-diabetes.

\section{Methods}

The search strategy was in accordance with the recommendations of the Meta-analysis of Observational Studies in Epidemiology (MOOSE) Group. ${ }^{9}$ We searched PubMed (1947 to 16 July 2011), Embase (1947 to 16 July 2011), and the Cochrane Library (1947 to 16 July 2011), using the search terms "prediabetes" or "impaired fasting glucose" or "impaired glucose intolerance" or "borderline diabetes" AND "cardiovascular disease" or "myocardial ischemia" or "myocardial infarct" or "ischemic heart disease" or "coronary heart disease" or "coronary artery disease" or "angina" or "stroke" or "cerebrovascular disease" or "cerebrovascular attack" or "cerebral ischemia" or "brain ischemia" or "intracranial hemorrhage" AND "cohort" or "observational" or "prospective" or "trial." We restricted the search to studies in humans and applied no language restrictions. We retrieved further information by a manual search of references from recent reviews and relevant published original studies.

\section{Inclusion and exclusion criteria}

We selected studies if they met the following entry criteria: prospectively collected data within cohort studies or clinical trials; blood glucose evaluated at baseline; assessed stroke event as an endpoint during the follow-up period (for example, if a person had a stroke before enrolment, the stroke event during follow-up would be recurrent stroke; if a person did not have a stroke before enrolment, the stroke event during follow-up would be the first stroke event); intended follow-up of at least one year for all participants; and reported quantitative estimates of the multivariate adjusted (that is, age, sex, and one other conventional vascular risk factor as minimum requirements) relative risk and $95 \%$ confidence interval or standard error for the log relative risk for future stroke associated with baseline pre-diabetes. Pre-diabetes was defined as impaired fasting glucose (fasting glucose $100-125 \mathrm{mg} / \mathrm{dL}$ or $110-125 \mathrm{mg} / \mathrm{dL}^{56}$ ) or impaired glucose tolerance (two hour values in the oral glucose tolerance test of 140-199 mg/dL (7.8-11.0 mmol/L)). ${ }^{4}$ The reference group (that is, normoglycaemia) included people with fasting glucose less than $100 \mathrm{mg} / \mathrm{dL}$, fasting glucose less than $110 \mathrm{mg} / \mathrm{dL}$, or non-fasting glucose less than $140 \mathrm{mg} / \mathrm{dL}$. Although we preferred studies that measured baseline fasting plasma glucose and oral glucose tolerance test, in the main analysis we did not exclude studies that measured only baseline fasting or non-fasting glucose concentrations. So, for instance, people with a fasting plasma glucose of $126 \mathrm{mg} / \mathrm{dL}$ or greater (that is, diabetes mellitus) may have inadvertently been included if only non-fasting glucose was measured; on the other hand, people with a non-fasting glucose of $200 \mathrm{mg} / \mathrm{dL}$ or greater (that is, diabetes mellitus) might have been included if a study measured only fasting glucose. We also did a sensitivity analysis that excluded studies that might have inadvertently enrolled people who met the criterion for a diagnosis of diabetes. Finally, we also excluded studies in which more than $50 \%$ of participants were pregnant women.

\section{Data extraction and quality assessment}

Two investigators (ML and KSH) independently abstracted data from eligible studies. Discrepancies were resolved by discussion with a third investigator (BO) and by referencing the original report. Relevant data included the first author's name, study name, year of publication, country of origin, number of participants, age of participants, duration of follow-up, percentage of participants followed to the end of a study, outcome assessment, prevalence of pre-diabetes, multivariate adjusted relative risks or hazard ratios for stroke and corresponding $95 \%$ confidence interval, and covariates adjusted for in the statistical analysis.

We assessed studies' quality on the basis of adequate adjustment for potential confounders (at least six of seven factors: age, sex, hypertension or systolic blood pressure or antihypertensive drug, body mass index or other measure of overweight/obesity, physical activity, cholesterol concentration or statin use, and smoking).

\section{Statistical analysis}

We used multivariate adjusted outcome data for our data analysis. We converted these values in every study by using their natural logarithms and calculated the standard errors from these logarithmic numbers and their corresponding $95 \%$ confidence intervals. The statistical analysis used the inverse variance approach to combine log relative risks and standard errors. We used a random effect model and assessed heterogeneity by $\mathrm{P}$ value of $\tau^{2}$ statistics. ${ }^{10} \mathrm{We}$ used a funnel plot based on the primary outcome to evaluate potential systematic bias in studies, including publication bias. All reported $\mathrm{P}$ values were two sided with significance set at less than 0.05 .

We calculated summary estimates of relative risk for fasting glucose of 100 to $125 \mathrm{mg} / \mathrm{dl}$, fasting glucose of 110 to 125 $\mathrm{mg} / \mathrm{dL}$, and presence of impaired glucose tolerance with or without impaired fasting glucose. We did predefined subgroup analyses according to population type (general population versus established cardiovascular disease at entry), ethnicity (Asians versus non-Asians), sex (men versus women versus both men and women), mean age at entry ( $<65$ years versus $\geq 65$ years), possibility of enrolling patients with diabetes (none enrolled versus might be enrolled), and adjustment for confounders (adequate adjustment versus inadequate adjustment). We used the Cochrane Collaboration's Review Manager software package (RevMan 5) for the meta-analysis of observational studies. ${ }^{11} 12$

\section{Results}

The literature review identified 62 full articles for detailed assessment. We excluded 29 studies owing to lack of a multivariate adjusted stroke estimate, seven studies for providing only fatal endpoints; two studies for follow-up duration less than one year; eight studies for lacking proper impaired fasting glucose or impaired glucose tolerance categories at baseline ${ }^{13-20}$ and one study that was retrospective rather than prospective (fig $1 \Downarrow)$. The final analysis included 760925 participants from 15 prospective cohort studies. ${ }^{21-35}$ All studies excluded people with fasting glucose of $126 \mathrm{mg} / \mathrm{dL}$ or greater, except one study in which only non-fasting glucose was measured at baseline. ${ }^{33}$ In this study, impaired glucose tolerance was defined as non-fasting venous plasma glucose 140 to $199 \mathrm{mg} / \mathrm{dL}$, and a non-fasting glucose below $140 \mathrm{mg} / \mathrm{dL}$ was used as a reference; a few patients 
with fasting glucose of $126 \mathrm{mg} / \mathrm{dL}$ or greater might thus have been enrolled in the impaired glucose tolerance group or reference group..$^{33}$ On the other hand, among 15 included studies, seven studies measured only fasting glucose at baseline ${ }^{24} 252729313234$; so some people with non-fasting glucose of $200 \mathrm{mg} / \mathrm{dL}$ or greater might have be included in these studies.

Table $1 \Downarrow$ shows the characteristics of the studies. Among the 15 studies, nine were derived from the general population, one from the aged population, four from populations with a history of coronary artery disease, and one from a population with history of stroke or transient ischemic attack. Ten studies reported any stroke as an endpoint, four reported ischaemic stroke as an endpoint, and one reported ischaemic and haemorrhagic strokes separately as endpoints. Sample sizes ranged from 1032 to 652 901, and follow-up durations ranged from one year to 17 years. One study enrolled only women, and another enrolled only men; the remainder enrolled both men and women.

In eight studies with information about fasting glucose 100 to $125 \mathrm{mg} / \mathrm{dL}$, the random effects summary estimate did not show increased risk of stroke after adjustment for established cardiovascular risk factors (relative risk $1.08,95 \%$ confidence interval 0.94 to $1.23 ; \mathrm{P}=0.26$ ) (fig $2 \Downarrow$ ). We found evidence of heterogeneity across studies ( $\mathrm{P}$ for heterogeneity $<0.0001$ ) but no major asymmetrical appearance in the funnel plot (supplementary fig A).

In five studies with information about fasting glucose 110 to $125 \mathrm{mg} / \mathrm{dL}$, the random effects summary estimate showed an increased risk of stroke after adjustment for established cardiovascular risk factors (relative risk 1.21, 1.02 to 1.44; $\mathrm{P}=0.03$ ) (fig $3 \Downarrow$ ). Although we again found evidence of heterogeneity across studies ( $\mathrm{P}$ for heterogeneity 0.003 ), we saw no substantial asymmetrical appearance in the funnel plot (supplementary fig B).

Eight studies had information about impaired glucose tolerance or combination of impaired fasting glucose and impaired glucose tolerance. The random effects summary estimate for these studies showed an increased risk of stroke after adjustment for established cardiovascular risk factors (relative risk 1.26, 1.10 to $1.43 ; \mathrm{P}<0.001$ ) (fig $4 \Downarrow$ ). We found no obvious heterogeneity across studies $(\mathrm{P}=0.15)$ and no major asymmetric appearance in the funnel plot (supplementary fig C).

In a sensitivity analysis excluding the study that might have enrolled people with fasting glucose of $126 \mathrm{mg} / \mathrm{dL}$ or above, ${ }^{33}$ we saw a smaller, but still significant, effect of impaired glucose tolerance or combination of impaired fasting glucose and impaired glucose tolerance on future stroke (relative risk 1.20, 1.07 to $1.35 ; \mathrm{P}=0.002$ ). However, when we excluded studies that might have enrolled people with non-fasting glucose of 200 $\mathrm{mg} / \mathrm{dL}$ or above, neither fasting glucose 100 to $125 \mathrm{mg} / \mathrm{dL}$ nor 110 to $125 \mathrm{mg} / \mathrm{dL}$ was significantly associated with increased risk of future stroke (relative risks $0.91,0.50$ to 1.63 , and 1.11, 0.77 to 1.61 ) (table $2 \Downarrow$ ).

Table $2 \Downarrow$ shows subgroup analyses. Heterogeneity existed between estimates among participants' ages at entry $(<65$ years versus $\geq 65$ years) and degree of adjustment for confounders (adequate adjustment versus inadequate adjustment). In four studies with adequate adjustment of confounders, baseline impaired glucose tolerance or combination of impaired fasting glucose and impaired glucose tolerance was associated with a trend towards higher future risk of stroke (relative risk 1.11, 0.99 to $1.25 ; \mathrm{P}=0.08)$. We further analysed three studies that provided information on participants with fasting glucose of
100 to $109 \mathrm{mg} / \mathrm{dL}$ and found no associated increased risk of stroke (relative risk $0.94,0.73$ to $1.20 ; \mathrm{P}=0.61$ ).

\section{Discussion}

In this meta-analysis of 15 prospective studies, with more than 760000 participants, we found that people with baseline pre-diabetes, defined as impaired fasting glucose of 110 to 125 $\mathrm{mg} / \mathrm{dL}$ (6.1-6.9 mmol/L) or presence of impaired glucose tolerance, were at modestly higher risk of future stroke. The American Diabetes Association's current, less stringent impaired fasting glucose definition (fasting glucose $100-125 \mathrm{mg} / \mathrm{dL}$ (5.6-6.9 mmol/L)) of pre-diabetes was not associated with increased risk of stroke. After further exclusion of studies that may have enrolled patients with diabetes, only impaired glucose tolerance or a combination of impaired fasting glucose and impaired glucose tolerance showed significant relation with risk of stroke. The observed lack of a relation between impaired fasting glucose and risk of future stroke is in accord with results from a recent individual level collaborative meta-analysis. ${ }^{36} \mathrm{It}$ reinforces the notion that two hour postprandial glucose challenge is probably a stronger predictor of macrovascular complications than is fasting glucose. ${ }^{37}$

The risk of stroke seems to rise progressively across the spectrum of insulin resistance from impaired fasting glucose to impaired glucose tolerance to diabetes ${ }^{37}$ suggesting that hyperglycaemia might be a continuous risk factor for stroke. Nonetheless, people with pre-diabetes can be as insulin resistant as people with diabetes. ${ }^{38}$ A common mechanism linking all components of the insulin resistance syndrome is the cellular/molecular cause of the insulin resistance, ${ }^{38}{ }^{39}$ which not only promotes atherogenesis and inflammation but also leads to or aggravates other components of the syndrome, which themselves are major vascular risk factors. Also, people with pre-diabetes develop dyslipidaemia characterised by small, dense, atherogenic low density lipoprotein particles, hypertriglyceridaemia, and reduced high density lipoprotein cholesterol, ${ }^{40}$ as well as accelerated atherogenesis. ${ }^{42}$

All of the aforementioned notwithstanding, the relation of pre-diabetes with risk of future stroke was relatively modest, so underlying confounding is probably easily able to affect these results. Furthermore, compared with the studies with inadequate adjustment of confounders, the effect size of the association of pre-diabetes with stroke risk was attenuated in those studies that used adequate adjustment.

We found that the definition of pre-diabetes seems to matter with regard to risk of stroke. Even though insulin resistance may be a condition on a continuous scale, when it comes to stroke, the only diagnostic approach for pre-diabetes that is clearly linked to risk seems to be one that includes impairment in glucose tolerance. Of note, the American Diabetes Association recently updated its screening recommendation for pre-diabetes to include haemoglobin $\mathrm{A}_{1 \mathrm{c}}$ as another diagnostic testing option. ${ }^{4}$ These recommendations state that an haemoglobin $\mathrm{A}_{\mathrm{lc}}$ between $5.7 \%$ and $6.4 \%$ identifies people at high risk of diabetes and that the label of pre-diabetes can be applied. ${ }^{4} \mathrm{We}$ did not include haemoglobin $\mathrm{A}_{1 \mathrm{c}}$ criteria in the investigation of the association between pre-diabetes and risk of stroke because this recent diagnostic criterion had not yet been proposed when the prospective cohort studies we evaluated were conducted. Ongoing or future prospective cohort studies that include haemoglobin $\mathrm{A}_{\mathrm{lc}}$ among their baseline variables may provide more information on the association between pre-diabetes and risk of stroke. 


\section{Strengths and limitations of study}

Our study has several limitations. Firstly, a large amount of heterogeneity was observed in the results of the various studies. Although we did subgroup analyses, heterogeneity persisted in many subgroups, suggesting that other factors might explain some results. Despite these limitations, the results of this systematic review are possibly the most precise estimate available of the nature and strength of the relation between pre-diabetes and future risk of stroke. Secondly, knowing whether strokes occurred before or after diagnosis of diabetes during the study period would have been helpful. Such information might have clarified to what degree pre-diabetes itself is a risk factor or whether it simply reflects the risk associated with development of overt diabetes. Thirdly, $85 \%$ of the patients in the 15 included studies were enrolled in one study (which enrolled only Korean men). ${ }^{31}$ However, the weight of this study was actually only $17 \%$ in the analysis of fasting glucose 100 to $125 \mathrm{mg} / \mathrm{dL}$ and $27 \%$ in the analysis of fasting glucose 110 to $125 \mathrm{mg} / \mathrm{dL}$. Fourthly, although most studies included in this meta-analysis used all stroke as an endpoint, a few evaluated only ischaemic stroke as an endpoint. Fifthly, some people with diabetes mellitus at baseline might have been included in our analyses owing to the design of some studies in which only fasting or non-fasting glucose was measured, and determining the exact percentage of such patients in the pre-diabetes and reference groups was difficult. However, we still found a modest but increased risk of future stroke among people with impaired glucose tolerance or a combination of impaired fasting glucose and impaired glucose tolerance when we excluded studies that may have enrolled patients with diabetes.

\section{Conclusions and policy implications}

An immediate implication of our findings is that people with pre-diabetes should be aware that they are at increased risk of future stroke. Also, pre-diabetes is not only a risk factor for stroke but is also frequently associated with the presence of one or more other recognised major cardiovascular risk factors. ${ }^{7}$ When pre-diabetes is discovered, the person's overall cardiovascular risk factor profile should be reviewed to ensure that risk factors are being appropriately modified. Given the strong relation between being overweight/obese and pre-diabetes, recommending the maintenance of an ideal weight may improve clinical outcomes in these patients. For people with pre-diabetes, weight loss in conjunction with healthy lifestyle changes is associated with decreased risk of transitioning to frank diabetes and may even reduce future stroke events. ${ }^{43}{ }^{44}$ Our study also underscored a need to evaluate both fasting glucose and two hour postprandial glucose challenge for identifying people with pre-diabetes who may be at risk of stroke. Finally, randomised controlled trials evaluating the effect of glycaemic control on the occurrence of stroke among people with impaired glucose tolerance or a combination of impaired fasting glucose and impaired glucose tolerance are warranted.

\section{We thank Hsu-Han Wang for searching Embase.}

Contributors: ML and BO had the idea for the study. ML, JLS, and BO designed the inclusion and exclusion criteria. ML and KSH participated in the search and the data collection and extraction. ML did the statistical analysis with guidance from JLS and BO. ML wrote the first draft of the report, and JLS, SS, and BO did the major revision and made comments. All other authors commented on the draft and approved the final version. $\mathrm{ML}$ and $\mathrm{BO}$ are the guarantors.
Funding: ML was supported by a grant from Chang Gung Memorial Hospital, Taiwan (CMRPG 660311, Taiwan). JLS was supported by the specialised programme on translational research in acute stroke (SPOTRIAS) award (P50 NS044378) from the National Institutes of Health, and BO was supported by U01 NS079179 from the National Institutes of Health. The sponsors played no role in the study design, data collection and analysis, or decision to submit the article for publication.

Competing interests: All authors have completed the Unified Competing Interest form at www.icmje.org/coi_disclosure.pdf (available on request from the corresponding author) and declare: no support from any company for the submitted work; no financial relationships with any companies that might have an interest in the submitted work in the previous three years; and no other relationships or activities that could appear to have influenced the submitted work.

\section{Ethical approval: Not required.}

Data sharing: No additional data available.

1 Garber AJ, Handelsman Y, Einhorn D, Bergman DA, Bloomgarden ZT, Fonseca V, et al. Diagnosis and management of prediabetes in the continuum of hyperglycemia: when do the risks of diabetes begin? A consensus statement from the American College of Endocrinology and the American Association of Clinical Endocrinologists. Endocr Pract 2008;14:933-46.

2 Centers for Disease Control. National diabetes fact sheet, 2011. www.cdc.gov/diabetes/ pubs/pdf/ndfs_2011.pdf.

3 Geiss LS, James C, Gregg EW, Albright A, Williamson DF, Cowie CC. Diabetes risk reduction behaviors among U.S. adults with prediabetes. Am J Prev Med 2010;38:403-9.

4 Diagnosis and classification of diabetes mellitus. Diabetes Care 2011;34(suppl 1):S62-9.

5 Report of the Expert Committee on the Diagnosis and Classification of Diabetes Mellitus. Diabetes Care 1997;20:1183-97.

6 Expert Committee on the Diagnosis and Classification of Diabetes Mellitus. Report of the expert committee on the diagnosis and classification of diabetes mellitus. Diabetes Care 2003;26(suppl 1):S5-20.

7 DeFronzo RA, Abdul-Ghani M. Assessment and treatment of cardiovascular risk in prediabetes: impaired glucose tolerance and impaired fasting glucose. Am J Cardiol 2011;108(3 suppl):3-24B.

8 Ford ES, Zhao G, Li C. Pre-diabetes and the risk for cardiovascular disease: a systematic review of the evidence. J Am Coll Cardiol 2010;55:1310-7.

9 Stroup DF, Berlin JA, Morton SC, Olkin I, Williamson GD, Rennie D, et al. Meta-analysis of observational studies in epidemiology: a proposal for reporting. JAMA 2000;283:2008-12.

10 Rucker G, Schwarzer G, Carpenter JR, Schumacher M. Undue reliance on I(2) in assessing heterogeneity may mislead. BMC Med Res Methodol 2008;8:79.

11 Lee M, Saver JL, Chang B, Chang KH, Hao Q, Ovbiagele B. Presence of baseline prehypertension and risk of incident stroke: a meta-analysis. Neurology 2011;77:1330-37.

12 Lee M, Saver JL, Chang KC, Liao HW, Chang SC, Ovbiagele B. Impact of microalbuminuria on incident stroke: a meta-analysis. Stroke 2010;41:2625-31.

13 Lawes CM, Parag V, Bennett DA, Suh I, Lam TH, Whitlock G, et al. Blood glucose and risk of cardiovascular disease in the Asia Pacific region. Diabetes Care 2004;27:2836-42.

14 Kadowaki S, Okamura T, Hozawa A, Kadowaki T, Kadota A, Murakami Y, et al. Relationship of elevated casual blood glucose level with coronary heart disease, cardiovascular disease and all-cause mortality in a representative sample of the Japanese population: NIPPON DATA80. Diabetologia 2008;51:575-82.

15 Lawlor DA, Fraser A, Ebrahim S, Smith GD. Independent associations of fasting insulin, glucose, and glycated haemoglobin with stroke and coronary heart disease in older women. PLOS Med 2007;4:e263.

16 Eguchi K, Boden-Albala B, Jin Z, Di Tullio MR, Rundek T, Rodriguez CJ, et al. Usefulness of fasting blood glucose to predict vascular outcomes among individuals without diabetes mellitus (from the Northern Manhattan Study). Am J Cardiol 2007;100:1404-9.

17 Adams RJ, Appleton SL, Hill CL, Wilson DH, Taylor AW, Chittleborough CR, et al. Independent association of $\mathrm{HbA}(1 \mathrm{c})$ and incident cardiovascular disease in people without diabetes. Obesity (Silver Spring) 2009;17:559-63.

18 Qiao Q, Jousilahti P, Eriksson J, Tuomilehto J. Predictive properties of impaired glucose tolerance for cardiovascular risk are not explained by the development of overt diabetes during follow-up. Diabetes Care 2003;26:2910-4.

19 Hier DB, Foulkes MA, Swiontoniowski M, Sacco RL, Gorelick PB, Mohr JP, et al. Stroke recurrence within 2 years after ischemic infarction. Stroke 1991;22:155-61.

20 Welin L, Eriksson H, Larsson B, Ohlson LO, Svardsudd K, Tibblin G. Hyperinsulinaemia is not a major coronary risk factor in elderly men: the study of men born in 1913. Diabetologia 1992;35:766-70.

21 Doi Y, Ninomiya T, Hata J, Fukuhara M, Yonemoto K, Iwase M, et al. Impact of glucose tolerance status on development of ischemic stroke and coronary heart disease in a general Japanese population: the Hisayama study. Stroke 2010;41:203-9.

22 Hyvarinen M, Tuomilehto J, Mahonen M, Stehouwer CD, Pyorala K, Zethelius B, et al. Hyperglycemia and incidence of ischemic and hemorrhagic stroke-comparison between fasting and 2-hour glucose criteria. Stroke 2009;40:1633-7.

23 Iso H, Imano H, Kitamura A, Sato S, Naito Y, Tanigawa T, et al. Type 2 diabetes and risk of non-embolic ischaemic stroke in Japanese men and women. Diabetologia 2004; $47: 2137-44$.

24 Janszky I, Hallqvist J, Ljung R, Ahlbom A, Hammar N. Prognostic role of the glucometabolic status assessed in a metabolically stable phase after a first acute myocardial infarction: status assessed in a metabolically stable phase a
the SHEEP study. J Intern Med 2009;265:465-75.

25 Kanaya AM, Herrington D, Vittinghoff E, Lin F, Bittner V, Cauley JA, et al. Impaired fasting glucose and cardiovascular outcomes in postmenopausal women with coronary artery disease. Ann Intern Med 2005;142:813-20. 


\section{What is already known on this topic}

Pre-diabetes is a surging epidemic in many developed countries

Pre-diabetes has been linked to a modest rise in overall cardiovascular risk, but the effect of pre-diabetes on risk of future strokes has not been established

The definition of pre-diabetes includes presence of impaired fasting glucose, impaired glucose tolerance, or both

\section{What this study adds}

People with pre-diabetes on the basis of presence of impaired glucose tolerance had an independent risk of future stroke that was $20 \%$ greater than those with a normal glycaemia

The relation between pre-diabetes and risk of stroke seems to depend on the definition of pre-diabetes

Pre-diabetes based on a more recent guideline recommended definition of impaired fasting plasma glucose (100 to $125 \mathrm{mg} / \mathrm{dL}) \mathrm{was}$ not linked to future stroke risk

26 Kaarisalo MM, Raiha I, Arve S, Lehtonen A. Impaired glucose tolerance as a risk factor for stroke in a cohort of non-institutionalised people aged 70 years. Age Ageing 2006;35:592-6.

27 Kokubo Y, Okamura T, Watanabe M, Higashiyama A, Ono Y, Miyamoto Y, et al. The combined impact of blood pressure category and glucose abnormality on the incidence of cardiovascular diseases in a Japanese urban cohort: the Suita study. Hypertens Res 2010;33:1238-43.

28 Lenzen M, Ryden L, Ohrvik J, Bartnik M, Malmberg K, Scholte Op Reimer W, et al. Diabetes known or newly detected, but not impaired glucose regulation, has a negative influence on 1-year outcome in patients with coronary artery disease: a report from the Euro Heart Survey on diabetes and the heart. Eur Heart J 2006;27:2969-74.

29 Liu J, Grundy SM, Wang W, Smith SC Jr, Vega GL, Wu Z, et al. Ten-year risk of cardiovascular incidence related to diabetes, prediabetes, and the metabolic syndrome. Am Heart J 2007;153:552-8.

30 Oizumi T, Daimon M, Jimbu Y, Wada K, Kameda W, Susa S, et al. Impaired glucose tolerance is a risk factor for stroke in a Japanese sample-the Funagata study. Metabolism 2008;57:333-8.

31 Sung J, Song YM, Ebrahim S, Lawlor DA. Fasting blood glucose and the risk of stroke and myocardial infarction. Circulation 2009;119:812-9.

32 Tanne D, Koren-Morag N, Goldbourt U. Fasting plasma glucose and risk of incident ischemic stroke or transient ischemic attacks: a prospective cohort study. Stroke 2004;35:2351-5

33 Vermeer SE, Sandee W, Algra A, Koudstaal PJ, Kappelle LJ, Dippel DW. Impaired glucose tolerance increases stroke risk in nondiabetic patients with transient ischemic attack or minor ischemic stroke. Stroke 2006;37:1413-7.

34 Yeboah J, Bertoni AG, Herrington DM, Post WS, Burke GL. Impaired fasting glucose and the risk of incident diabetes mellitus and cardiovascular events in an adult population: MESA (multi-ethnic study of atherosclerosis). J Am Coll Cardiol 2011;58:140-6.

35 Zhang Y, Galloway JM, Welty TK, Wiebers DO, Whisnant JP, Devereux RB, et al. Incidence and risk factors for stroke in American Indians: the strong heart study. Circulation 2008;118:1577-84.

36 Sarwar N, Gao P, Seshasai SR, Gobin R, Kaptoge S, Di Angelantonio E, et al. Diabetes mellitus, fasting blood glucose concentration, and risk of vascular disease: a collaborative meta-analysis of 102 prospective studies. Lancet 2010;375:2215-22.
37 Glucose tolerance and cardiovascular mortality: comparison of fasting and 2-hour diagnostic criteria. Arch Intern Med 2001;161:397-405.

38 DeFronzo RA. Insulin resistance, lipotoxicity, type 2 diabetes and atherosclerosis: the missing links. The Claude Bernard lecture 2009. Diabetologia 2010;53:1270-87.

39 Bajaj M, Defronzo RA. Metabolic and molecular basis of insulin resistance. J Nucl Cardiol 2003;10:311-23.

40 Grundy SM. Metabolic syndrome pandemic. Arterioscler Thromb Vasc Biol 2008:28:629-36.

41 Rana JS, Visser ME, Arsenault BJ, Despres JP, Stroes ES, Kastelein JJ, et al. Metabolic dyslipidemia and risk of future coronary heart disease in apparently healthy men and women: the EPIC-Norfolk prospective population study. Int J Cardiol 2010;143:399-404.

42 Howard BV, Robbins DC, Sievers ML, Lee ET, Rhoades D, Devereux RB, et al. LDL cholesterol as a strong predictor of coronary heart disease in diabetic individuals with insulin resistance and low LDL: the strong heart study. Arterioscler Thromb Vasc Biol 2000:20:830-5.

43 Leblanc ES, O'Connor E, Whitlock EP, Patnode CD, Kapka T. Effectiveness of primary care-relevant treatments for obesity in adults: a systematic evidence review for the U.S. Preventive Services Task Force. Ann Intern Med 2011;155:434-47.

44 Hopper I, Billah B, Skiba M, Krum H. Prevention of diabetes and reduction in major cardiovascular events in studies of subjects with prediabetes: meta-analysis of randomised controlled clinical trials. Eur J Cardiovasc Prev Rehabil 2011;18:813-23.

\section{Accepted: 16 April 2012}

\section{Cite this as: BMJ 2012;344:e3564}

This is an open-access article distributed under the terms of the Creative Commons Attribution Non-commercial License, which permits use, distribution, and reproduction in any medium, provided the original work is properly cited, the use is non commercial and is otherwise in compliance with the license. See: http://creativecommons.org/licenses/by$\mathrm{nc} / 2.0 /$ and http://creativecommons.org/licenses/by-nc/2.0/legalcode. 


\section{Tables}

\section{Table 1/ Characteristics of included studies}

\begin{tabular}{|c|c|c|c|c|c|c|c|c|c|c|}
\hline $\begin{array}{l}\text { Study and } \\
\text { publication } \\
\text { year }\end{array}$ & Country & $\begin{array}{l}\text { Population } \\
\text { characteristics }^{*}\end{array}$ & $\begin{array}{c}\text { Sample } \\
\text { size of } \\
\text { cohorts } \\
\text { (\% } \\
\text { women) }\end{array}$ & $\begin{array}{l}\text { Average } \\
\text { age } \\
\text { (range } \\
\text { or SD) }\end{array}$ & $\begin{array}{c}\text { Years of } \\
\text { follow-up in } \\
\text { all } \\
\text { participants } \\
\text { (\% followed } \\
\text { up to or } \\
\text { died before } \\
\text { stated time } \\
\text { point) }\end{array}$ & $\begin{array}{l}\text { Prevalence } \\
\text { of } \\
\text { pre-diabetes }\end{array}$ & $\begin{array}{c}\text { Baseline } \\
\text { pre-diabetes } \\
\text { category and } \\
\text { definition }\end{array}$ & $\begin{array}{l}\text { Endpoint } \\
\text { assessed } \\
\text { during } \\
\text { follow-up }\end{array}$ & $\begin{array}{l}\text { Adjustment } \\
\text { variables }\end{array}$ & $\begin{array}{l}\text { Adjustment } \\
\text { for } \\
\text { confounders } †\end{array}$ \\
\hline Doi $2010^{21}$ & Japan & $\begin{array}{l}\text { General, } \\
\text { excluded history } \\
\text { of CVD } \\
\text { (excluded all } \\
\text { diabetes) }\end{array}$ & $\begin{array}{l}2421 \\
(57 \%)\end{array}$ & $58(10)$ & $14(100 \%)$ & NA & $\begin{array}{c}\text { IFG } 100, \text { IFG } \\
110, \text { IGT }\end{array}$ & $\begin{array}{l}\text { Ischaemic } \\
\text { stroke }\end{array}$ & $\begin{array}{l}\text { Age, sex, SBP, } \\
\text { ECG abnormalities, } \\
\text { BMI, total and HDL } \\
\text { cholesterol, smoking } \\
\text { habits, alcohol } \\
\text { intake, and regular } \\
\text { exercise }\end{array}$ & Adequate \\
\hline $\begin{array}{l}\text { Hyvärinen } \\
2009^{22}\end{array}$ & $\begin{array}{l}\text { Finland, } \\
\text { Sweden }\end{array}$ & $\begin{array}{l}\text { General } \\
\text { (excluded all } \\
\text { diabetes) }\end{array}$ & $\begin{array}{l}18360 \\
(54 \%)\end{array}$ & $\begin{array}{c}55 \\
(20-90)\end{array}$ & $\begin{array}{l}12.9 \text { (not } \\
\text { reported) }\end{array}$ & $22 \%$ & IFG 110, IGT & All stroke & $\begin{array}{l}\text { Age, sex, centre, } \\
\text { MAP, BMI, total } \\
\text { cholesterol, and } \\
\text { smoking status }\end{array}$ & Adequate \\
\hline Iso $2004^{23}$ & Japan & $\begin{array}{l}\text { General, } \\
\text { excluded history } \\
\text { of CVD } \\
\text { (excluded all } \\
\text { diabetes) }\end{array}$ & $\begin{array}{l}10582 \\
(59 \%)\end{array}$ & $\begin{array}{c}53 \\
(40-69)\end{array}$ & $\begin{array}{l}17 \text { (not } \\
\text { reported) }\end{array}$ & $7 \%$ & IFG 110, IGT & $\begin{array}{l}\text { Ischaemic } \\
\text { stroke }\end{array}$ & $\begin{array}{l}\text { Age, sex, } \\
\text { community, } \\
\text { hypertension status, } \\
\text { BMI, TSF, SSF, } \\
\text { total and HDL } \\
\text { cholesterol, smoking } \\
\text { status, alcohol } \\
\text { intake, and (for } \\
\text { women) } \\
\text { menopausal status }\end{array}$ & Adequate \\
\hline $\begin{array}{l}\text { Janszky } \\
2009^{24}\end{array}$ & Sweden & $\begin{array}{l}\text { CAD (might } \\
\text { include } \\
\text { non-fasting } \\
\text { glucose } \geq 200 \\
\text { mg/dL) }\end{array}$ & $\begin{array}{c}1167 \\
(30 \%)\end{array}$ & $\begin{array}{c}59 \\
(45-70)\end{array}$ & $\begin{array}{l}8 \text { (not } \\
\text { reported) }\end{array}$ & $22 \%$ & IFG 100 & All stroke & $\begin{array}{l}\text { Age, sex, obesity, } \\
\text { hypertension, } \\
\text { physical activity, } \\
\text { total cholesterol, } \\
\text { triglycerides, apo } \\
\text { B:apo A ratio, Q } \\
\text { wave infarction, and } \\
\text { education }\end{array}$ & Adequate \\
\hline $\begin{array}{l}\text { Kaarisalo } \\
2006^{26}\end{array}$ & Finland & $\begin{array}{l}70 \text {-year-old } \\
\text { people (excluded } \\
\text { all diabetes) }\end{array}$ & $\begin{array}{r}1032 \\
(52 \%)\end{array}$ & 70 & $\begin{array}{l}9.6 \text { (not } \\
\text { reported) }\end{array}$ & $12 \%$ & IGT & $\begin{array}{l}\text { Ischaemic } \\
\text { stroke }\end{array}$ & $\begin{array}{l}\text { Sex, previous stroke } \\
\text { or TIA, atrial } \\
\text { fibrillation, history of } \\
\text { MI, HF, poorly } \\
\text { controlled } \\
\text { hypertension (SBP } \\
\geq 160 \mathrm{~mm} \mathrm{Hg} \text { or } \\
\text { DBP } \geq 95 \mathrm{~mm} \mathrm{Hg} \text {, } \\
\text { current smoking, } \\
\text { acetylsalicylic acid } \\
\text { use, normal memory }\end{array}$ & Not adequate \\
\hline $\begin{array}{l}\text { Kanaya } \\
2005^{25}\end{array}$ & USA & $\begin{array}{l}\text { Postmenopausal } \\
\text { women with CAD } \\
\text { (might include } \\
\text { non-fasting } \\
\text { glucose } \geq 200 \\
\mathrm{mg} / \mathrm{dL} \text { ) }\end{array}$ & $\begin{array}{c}2763 \\
(100 \%)\end{array}$ & $\begin{array}{c}67 \\
(44-79)\end{array}$ & $6.8(93.7 \%)$ & $25 \%$ & IFG 100 & $\begin{array}{l}\text { All stroke and } \\
\text { transient } \\
\text { ischaemic } \\
\text { attack }\end{array}$ & $\begin{array}{l}\text { Age, current } \\
\text { smoking, physical } \\
\text { activity, alcoholic } \\
\text { drinks/week, BMI, } \\
\text { overall health } \\
\text { status, use of } \\
\text { statins, diuretics, } \\
\text { ACEI and hormone } \\
\text { therapy, assignment } \\
\text { time dependent } \\
\text { covariates, race or } \\
\text { ethnicity, education, } \\
\text { previous PTCA, } \\
\text { previous CABG, } \\
\text { sign of HF, and >1 } \\
\text { previous MI, using } \\
\text { baseline covariates; }\end{array}$ & Adequate \\
\hline
\end{tabular}




\section{Table 1 (continued)}

\begin{tabular}{|c|c|c|c|c|c|c|c|c|c|c|}
\hline \multirow[t]{2}{*}{$\begin{array}{l}\text { Study and } \\
\text { publication } \\
\text { year }\end{array}$} & Country & $\begin{array}{l}\text { Population } \\
\text { characteristics }^{*}\end{array}$ & $\begin{array}{c}\text { Sample } \\
\text { size of } \\
\text { cohorts } \\
\text { (\% } \\
\text { women) }\end{array}$ & $\begin{array}{l}\text { Average } \\
\text { age } \\
\text { (range } \\
\text { or SD) }\end{array}$ & $\begin{array}{l}\text { Years of } \\
\text { follow-up in } \\
\text { all } \\
\text { participants } \\
\text { (\% followed } \\
\text { up to or } \\
\text { died before } \\
\text { stated time } \\
\text { point) }\end{array}$ & $\begin{array}{l}\text { Prevalence } \\
\text { of } \\
\text { pre-diabetes }\end{array}$ & $\begin{array}{l}\text { Baseline } \\
\text { pre-diabetes } \\
\text { category and } \\
\text { definition }\end{array}$ & $\begin{array}{l}\text { Endpoint } \\
\text { assessed } \\
\text { during } \\
\text { follow-up }\end{array}$ & $\begin{array}{l}\text { Adjustment } \\
\text { variables }\end{array}$ & $\begin{array}{l}\text { Adjustment } \\
\text { for } \\
\text { confounders } †\end{array}$ \\
\hline & & & & & & & & & $\begin{array}{l}\text { stratified by clinical } \\
\text { centre }\end{array}$ & \\
\hline $\begin{array}{l}\text { Kokubo } \\
2010^{27}\end{array}$ & Japan & $\begin{array}{l}\text { General, } \\
\text { excluded history } \\
\text { of CVD (might } \\
\text { include } \\
\text { non-fasting } \\
\text { glucose } \geq 200 \\
\mathrm{mg} / \mathrm{dL} \text { ) }\end{array}$ & $\begin{array}{l}5321 \\
(53 \%)\end{array}$ & $\begin{array}{c}55 \\
(30-79)\end{array}$ & 11.7 (100\%) & $28 \%$ & IFG 100 & All stroke & $\begin{array}{l}\text { Age, sex, BMI, } \\
\text { hypertension, } \\
\text { hyperlipidaemia, } \\
\text { and smoking and } \\
\text { drinking status }\end{array}$ & Not adequate \\
\hline $\begin{array}{l}\text { Lezen } \\
2006^{28}\end{array}$ & Europe & $\begin{array}{l}\text { CAD (excluded } \\
\text { all diabetes) }\end{array}$ & $\begin{array}{l}4676 \\
(70 \%)\end{array}$ & $65(11)$ & $\begin{array}{l}1 \text { (not } \\
\text { reported) }\end{array}$ & $24 \%$ & IFG 110, IGT & All stroke & $\begin{array}{l}\text { Age, sex, history of } \\
\text { MI, HF, PVD, } \\
\text { stroke, } \\
\text { hyperlipidaemia, } \\
\text { diagnosis at } \\
\text { admission, and } \\
\text { treatment with } \\
\text { anti-thrombotic } \\
\text { drugs, lipid lowering } \\
\text { drugs, and } \beta \\
\text { blockers }\end{array}$ & Not adequate \\
\hline Liu $2007^{29}$ & China & $\begin{array}{l}\text { General, } \\
\text { excluded history } \\
\text { of CVD (might } \\
\text { include } \\
\text { non-fasting } \\
\text { glucose } \geq 200 \\
\mathrm{mg} / \mathrm{dL} \text { ) }\end{array}$ & $\begin{array}{l}30378 \\
(47 \%)\end{array}$ & $\begin{array}{c}47 \\
(35-64)\end{array}$ & $10(94 \%)$ & $21 \%$ & IFG 100 & $\begin{array}{l}\text { Ischaemic } \\
\text { and } \\
\text { haemorrhagic } \\
\text { stroke } \\
\text { separately }\end{array}$ & $\begin{array}{l}\text { Age, sex, smoking, } \\
\text { CVD family history, } \\
\text { and elevated total } \\
\text { cholesterol }\end{array}$ & Not adequate \\
\hline $\begin{array}{l}\text { Oizumi } \\
2008^{30}\end{array}$ & Japan & $\begin{array}{l}\text { General, } \\
\text { excluded history } \\
\text { of stroke }\end{array}$ & $\begin{array}{l}2938 \\
(56 \%)\end{array}$ & $57(>35)$ & $\begin{array}{l}9.7 \text { (not } \\
\text { reported) }\end{array}$ & $15 \%$ & IGT & All stroke & $\begin{array}{l}\text { Age, sex, } \\
\text { hypertension }\end{array}$ & Not adequate \\
\hline Sung $2009^{31}$ & Korea & $\begin{array}{l}\text { General, men } \\
\text { (might include } \\
\text { non-fasting } \\
\text { glucose } \geq 200 \\
\text { mg/dL) }\end{array}$ & $\begin{array}{c}652901 \\
(0 \%)\end{array}$ & $\begin{array}{c}43 \\
(30-64)\end{array}$ & $\begin{array}{l}8.8 \text { (not } \\
\text { reported) }\end{array}$ & $13 \%$ & $\begin{array}{c}\text { IFG 100, IFG } \\
110\end{array}$ & All stroke & $\begin{array}{l}\text { Age, height, } \\
\text { smoking, alcohol } \\
\text { consumption, } \\
\text { regular exercise, } \\
\text { level of monthly } \\
\text { salary, area of } \\
\text { residence, BP, total } \\
\text { cholesterol, BMI }\end{array}$ & Adequate \\
\hline $\begin{array}{l}\text { Tanne } \\
2004^{32}\end{array}$ & Israel & $\begin{array}{l}\text { CAD (might } \\
\text { include } \\
\text { non-fasting } \\
\text { glucose } \geq 200 \\
\text { mg/dL) }\end{array}$ & $\begin{array}{l}13999 \\
(34 \%)\end{array}$ & $\begin{array}{c}60 \\
(45-74)\end{array}$ & $\begin{array}{l}7 \text { (not } \\
\text { reported) }\end{array}$ & $30 \%$ & $\begin{array}{c}\text { IFG } 100, \text { IFG } \\
110\end{array}$ & $\begin{array}{l}\text { Ischaemic } \\
\text { stroke and } \\
\text { TIA }\end{array}$ & $\begin{array}{l}\text { Age, sex, BMI, } \\
\text { hypertension, } \\
\text { triglycerides, \% } \\
\text { HDL, and use of } \\
\text { antiplatelets or } \\
\text { antihypertensives. }\end{array}$ & Adequate \\
\hline $\begin{array}{l}\text { Vermeer } \\
2006^{33}\end{array}$ & Netherlands & $\begin{array}{l}\text { TIA or minor } \\
\text { stroke (might } \\
\text { include fasting } \\
\text { glucose } \geq 126 \\
\mathrm{mg} / \mathrm{dL} \text { ) }\end{array}$ & $\begin{array}{l}3127 \\
(35 \%)\end{array}$ & $65(10)$ & $\begin{array}{l}2.6 \text { (not } \\
\text { reported) }\end{array}$ & $5 \%$ & IGT & All stroke & $\begin{array}{l}\text { Age, sex, smoking, } \\
\text { hypertension, and } \\
\text { minor ischaemic } \\
\text { stroke in history }\end{array}$ & Not adequate \\
\hline $\begin{array}{l}\text { Yeboah } \\
2011^{34}\end{array}$ & USA & $\begin{array}{l}\text { General, } \\
\text { excluded history } \\
\text { of CVD (might } \\
\text { include } \\
\text { non-fasting } \\
\text { glucose } \geq 200 \\
\mathrm{mg} / \mathrm{dL} \text { ) }\end{array}$ & $\begin{array}{l}6753 \\
(47 \%)\end{array}$ & $\begin{array}{c}62 \\
(45-84)\end{array}$ & $\begin{array}{l}7.5 \text { (not } \\
\text { reported) }\end{array}$ & $14 \%$ & IFG 100 & All stroke & $\begin{array}{l}\text { Age, sex, } \\
\text { race/ethnicity, SBP, } \\
\text { BMI, cigarette } \\
\text { smoking, total } \\
\text { cholesterol, } \\
\text { HDL-cholesterol, } \\
\text { triglycerides, blood } \\
\text { pressure drug use, } \\
\text { and statin use }\end{array}$ & Adequate \\
\hline
\end{tabular}




\section{Table 1 (continued)}

\begin{tabular}{|c|c|c|c|c|c|c|c|c|c|c|}
\hline $\begin{array}{l}\text { Study and } \\
\text { publication } \\
\text { year }\end{array}$ & Country & $\begin{array}{l}\text { Population } \\
\text { characteristics* }^{*}\end{array}$ & $\begin{array}{c}\text { Sample } \\
\text { size of } \\
\text { cohorts } \\
\text { (\% } \\
\text { women) }\end{array}$ & $\begin{array}{l}\text { Average } \\
\text { age } \\
\text { (range } \\
\text { or SD) }\end{array}$ & $\begin{array}{c}\text { Years of } \\
\text { follow-up in } \\
\text { all } \\
\text { participants } \\
\text { (\% followed } \\
\text { up to or } \\
\text { died before } \\
\text { stated time } \\
\text { point) }\end{array}$ & $\begin{array}{c}\text { Prevalence } \\
\text { of } \\
\text { pre-diabetes }\end{array}$ & $\begin{array}{c}\text { Baseline } \\
\text { pre-diabetes } \\
\text { category and } \\
\text { definition }\end{array}$ & $\begin{array}{l}\text { Endpoint } \\
\text { assessed } \\
\text { during } \\
\text { follow-up }\end{array}$ & $\begin{array}{l}\text { Adjustment } \\
\text { variables }\end{array}$ & $\begin{array}{l}\text { Adjustment } \\
\text { for } \\
\text { confounders } †\end{array}$ \\
\hline $\begin{array}{l}\text { Zhang } \\
2008^{35}\end{array}$ & USA & $\begin{array}{l}\text { American } \\
\text { Indians, excluded } \\
\text { history of stroke } \\
\text { (excluded all } \\
\text { diabetes) }\end{array}$ & $\begin{array}{l}4507 \\
(56 \%)\end{array}$ & $\begin{array}{c}60 \\
(45-74)\end{array}$ & $13.4(99.8 \%)$ & NA & $\begin{array}{l}\text { IFG } 110 \text { or } \\
\text { IGT }\end{array}$ & All stroke & $\begin{array}{l}\text { Age, sex, SBP, } \\
\text { DBP, BMI, waist } \\
\text { circumference, LDL } \\
\text { and HDL } \\
\text { cholesterol, } \\
\text { triglycerides, } \\
\text { physical activity, } \\
\text { smoking, alcohol } \\
\text { use, } \\
\text { microalbuminuria, } \\
\text { and } \\
\text { macroalbuminuria }\end{array}$ & Adequate \\
\hline
\end{tabular}

$\mathrm{ACEl}=$ angiotensin converting enzyme inhibitor; $\mathrm{BP}=$ blood pressure; $\mathrm{BMI}=$ body mass index; $\mathrm{CABG}=$ coronary artery bypass graft; $\mathrm{CAD}=$ coronary artery disease;

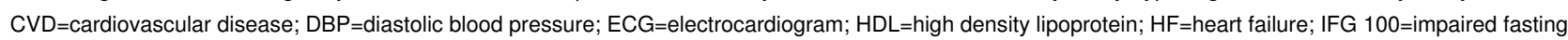
glucose (fasting glucose 100-125 mg/dL); IFG 110=impaired fasting glucose (fasting glucose 110-125 mg/dL); IGT=impaired glucose tolerance (post-challenge glucose 140-199 mg/dL); MAP=mean arterial pressure; $\mathrm{Ml}=$ myocardial infarction; $\mathrm{NA}=$ not available; $\mathrm{PTCA}=$ percutaneous transluminal coronary angiography; $\mathrm{PVD}=$ peripheral vascular disease; $\mathrm{SBP}=$ systolic blood pressure; $\mathrm{SSF}=$ subscapular skinfold thickness; TIA=transient ischaemic attack; TSF=triceps skinfold thickness.

*Including whether patients with diabetes may have been included because only fasting or non-fasting glucose was measured.

†Adequate adjustment denoted adjustment of at least six of seven factors: age, sex, hypertension or systolic blood pressure or antihypertensive drug, body mass index or other measure of overweight/obesity, physical activity, cholesterol concentration or statin use, and smoking. 


\begin{tabular}{|c|c|c|c|c|c|c|c|c|c|}
\hline \multirow[b]{2}{*}{ Subgroups } & \multicolumn{3}{|c|}{ Fasting glucose $100-125 \mathrm{mg} / \mathrm{dL}$} & \multicolumn{3}{|c|}{ Fasting glucose $110-125 \mathrm{mg} / \mathrm{dL}$} & \multicolumn{3}{|c|}{ IGT or combination of IFG/IGT } \\
\hline & $\begin{array}{c}\text { No of } \\
\text { studies }\end{array}$ & $\mathbf{R R}(95 \% \mathrm{Cl})$ & P value ${ }^{\star}$ & $\begin{array}{c}\text { No of } \\
\text { studies }\end{array}$ & $\mathbf{R R}(95 \% \mathrm{Cl})$ & P value* & $\begin{array}{c}\text { No of } \\
\text { studies }\end{array}$ & $\mathbf{R R}(95 \% \mathrm{Cl})$ & P value* \\
\hline Population: & & & 0.63 & & & 0.59 & & & 0.01 \\
\hline $\begin{array}{l}\text { Without CVD history } \\
\text { at entry }\end{array}$ & 5 & 1.05 (0.91 to 1.21$)$ & & 3 & 1.15 (0.99 to 1.33$)$ & & 6 & 1.18 (1.06 to 1.31$)$ & \\
\hline $\begin{array}{l}\text { With CVD history at } \\
\text { entry }\end{array}$ & 3 & $1.17(0.77$ to 1.76$)$ & & 2 & $1.36(0.75$ to 2.47$)$ & & 2 & 1.77 (1.30 to 2.40$)$ & \\
\hline Ethnicity: & & & 0.92 & & & 0.60 & & & 0.98 \\
\hline Asians & 4 & 1.07 (0.93 to 1.24$)$ & & 2 & $1.08(0.77$ to 1.52$)$ & & 4 & 1.24 (0.99 to 1.55$)$ & \\
\hline Non-Asians & 4 & 1.09 (0.77 to 1.55$)$ & & 3 & $1.21(0.94$ to 1.55$)$ & & 4 & $1.23(1.06$ to 1.44$)$ & \\
\hline Sex: & & & 0.21 & & & 0.44 & & & 0.09 \\
\hline Male & 3 & $0.91(0.67$ to 1.24$)$ & & 1 & $0.94(0.57$ to 1.55$)$ & & 2 & $0.95(0.72$ to 1.27$)$ & \\
\hline Female & 3 & 1.09 (0.79 to 1.49$)$ & & 1 & $1.22(0.78$ to 1.90$)$ & & 2 & $1.16(0.86$ to 1.56$)$ & \\
\hline Both & 4 & 1.25 (1.04 to 1.51$)$ & & 2 & 1.45 (0.94 to 2.24$)$ & & 6 & 1.37 (1.16 to 1.62$)$ & \\
\hline Mean age at entry: & & & 0.02 & & & - & & & 0.007 \\
\hline$<65$ years & 7 & $1.12(0.98$ to 1.28$)$ & & 5 & $1.21(1.02$ to 1.44$)$ & & 5 & 1.15 (1.03 to 1.29$)$ & \\
\hline$\geq 65$ years & 1 & $0.82(0.65$ to 1.03$)$ & & 0 & - & & 3 & 1.65 (1.30 to 2.08$)$ & \\
\hline $\begin{array}{l}\text { Possibility of enrolling } \\
\text { patients with diabetes: }\end{array}$ & & & 0.47 & & & 0.58 & & & 0.05 \\
\hline None enrolled & 1 & 0.91 (0.50 to 1.63$)$ & & 2 & $1.11(0.77$ to 1.61$)$ & & 7 & 1.20 (1.07 to 1.35$)$ & \\
\hline Might be enrolled & 7 & $1.13(0.99$ to 1.29$)$ & & 3 & 1.27 (0.95 to 1.72$)$ & & 1 & 1.80 (1.23 to 2.63$)$ & \\
\hline $\begin{array}{l}\text { Adjustment for } \\
\text { confounders: }\end{array}$ & & & 0.25 & & & - & & & 0.001 \\
\hline Adequate & 6 & $1.04(0.87$ to 1.25$)$ & & 5 & $1.21(1.02$ to 1.44$)$ & & 4 & $1.11(0.99$ to 1.25$)$ & \\
\hline Inadequate & 2 & 1.19 (1.05 to 1.36$)$ & & 0 & - & & 4 & 1.60 (1.32 to 1.93$)$ & \\
\hline
\end{tabular}




\section{Figures}

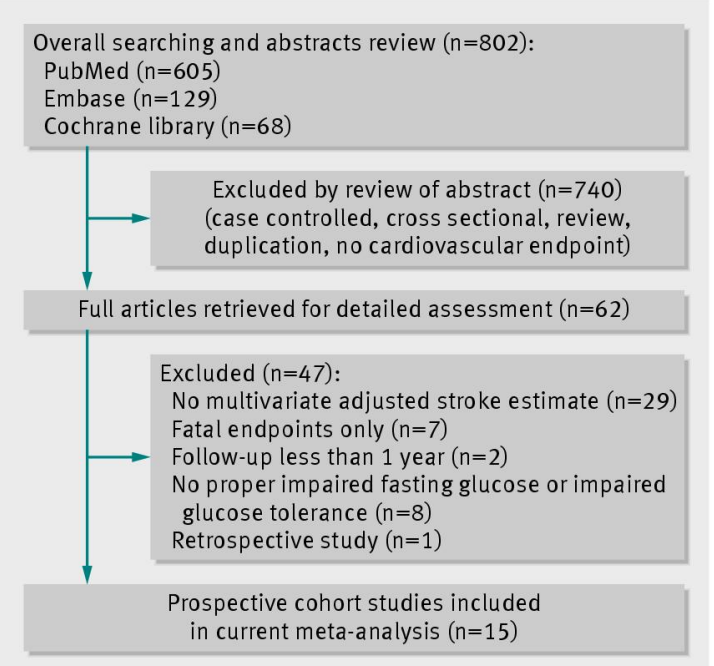

Fig 1 Study selection

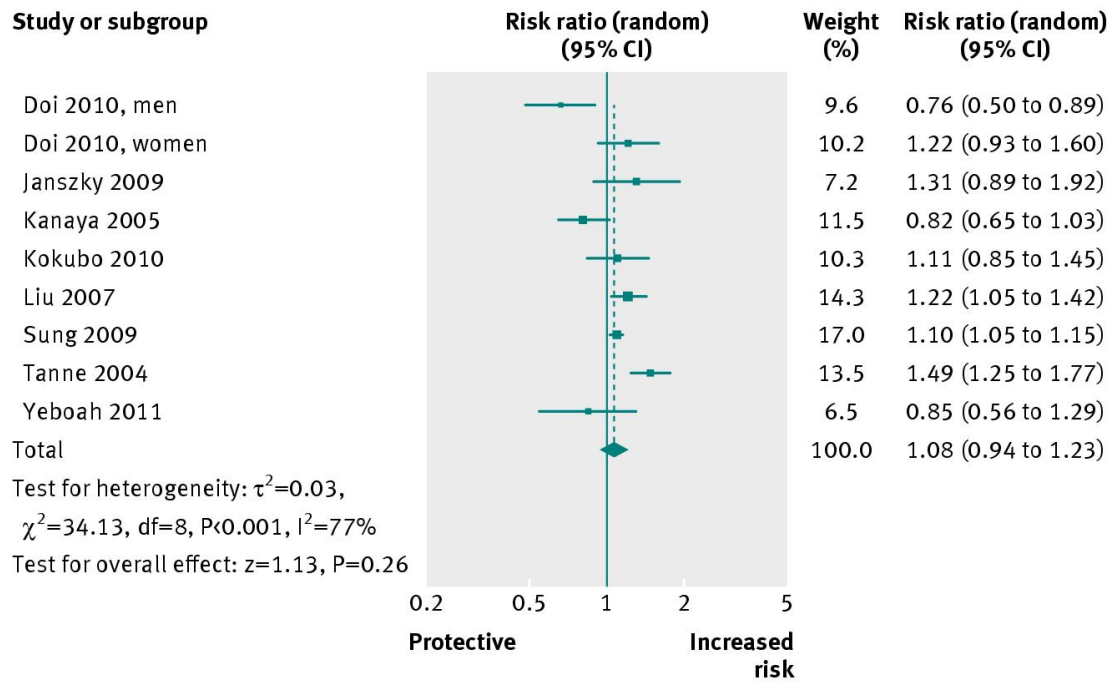

Fig 2 Baseline fasting glucose $100-125 \mathrm{mg} / \mathrm{dL}$ versus risk of stroke

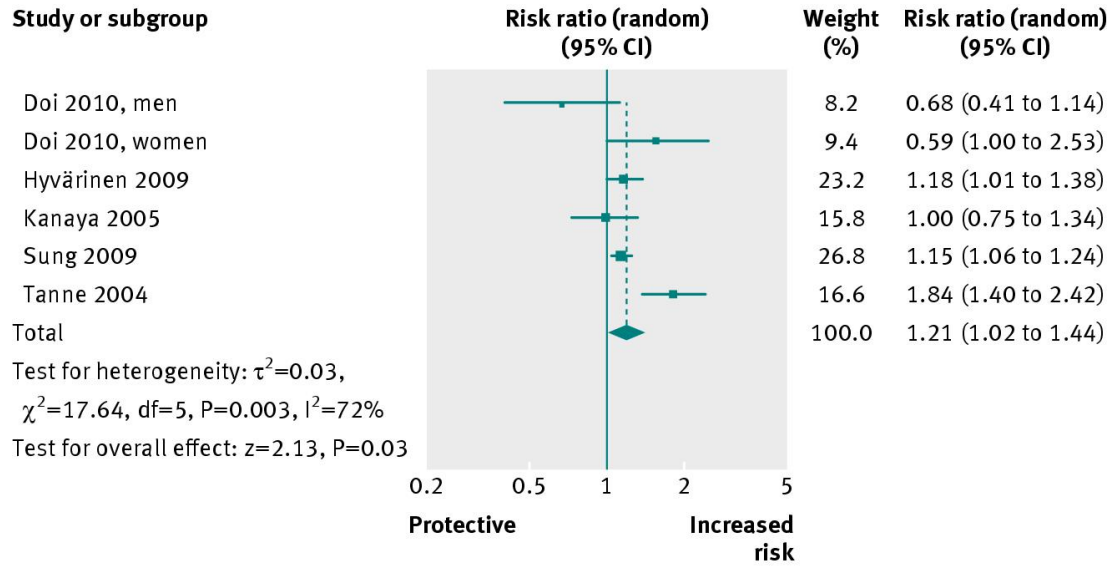

Fig 3 Baseline fasting glucose $110-125 \mathrm{mg} / \mathrm{dL}$ versus risk of stroke 


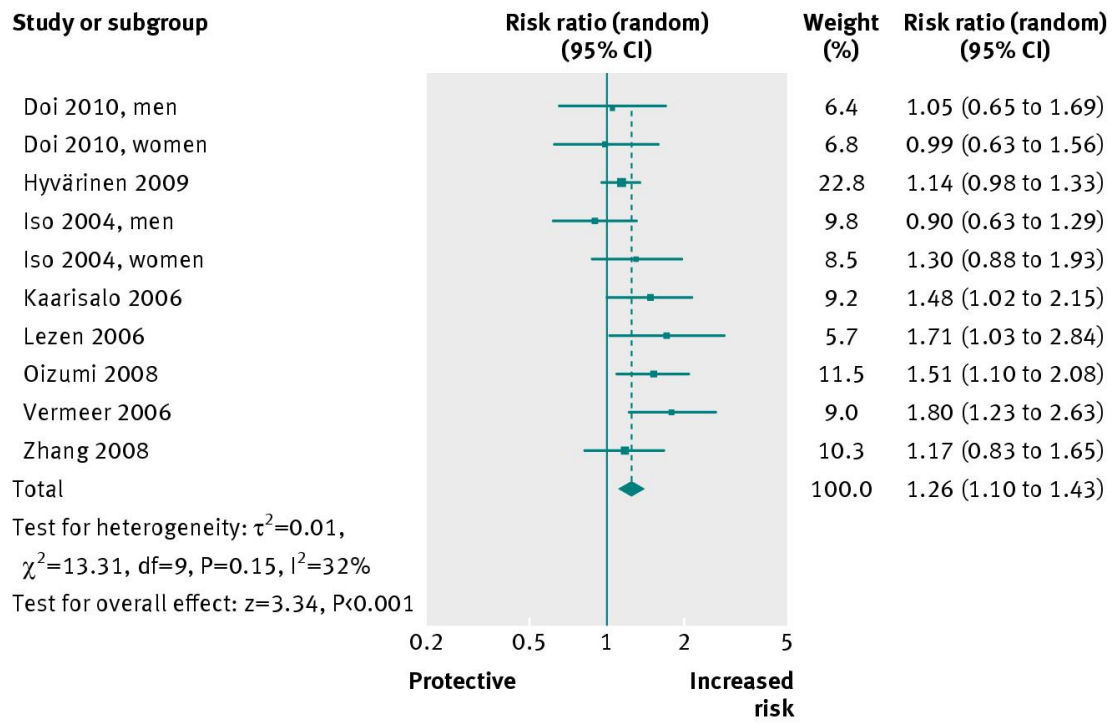

Fig 4 Baseline impaired glucose tolerance (IGT) or combination of IGT and impaired fasting glucose versus risk of stroke 